\title{
RESISTANCE RATES OF MYCOBACTERIUM TUBERCULOSIS COMPLEX ISOLA- TES OBTAINED FROM CLINICAL SAMPLES TO MAJOR ANTITUBERCULOUS DRUGS: A STUDY IN EDIRNE, TURKEY
}

\author{
Ozan Öner ${ }^{1}$, İnan Erdem Özdemir ${ }^{1}$, Kubilay Elmac1 ${ }^{1}$, Canan Eryıldız ${ }^{2}$ \\ ${ }^{1}$ Trakya University School of Medicine, Edirne, TURKEY \\ ${ }^{2}$ Department of Microbiology, Trakya University School of Medicine, Edirne, TURKEY
}

\section{ABSTRACT}

Aims: The aim of this study is to reveal the rates of the Mycobacterium tuberculosis complex resistance to major antituberculous drugs (streptomycin, isoniazid, rifampicin, ethambutol) by the evaluation of the specimens that are sent to Trakya University Hospital Microbiology Laboratory.

Methods: In this study, laboratory data of the cases that were pre-diagnosed with tuberculosis between 11/02/2016 and 31/12/2017 were scanned retrospectively. To compare the annual data descriptive statistics as arithmetic mean, numbers and percentages were used.

Results: Out of 4752 samples, 133 (2.79\%) were culture positive. 120 isolates were identified as Mycobacterium tuberculosis complex, while other 13 were defined as Mycobacterium other than tuberculosis. Antimycobacterial susceptibility tests showed that $9(7.5 \%)$ isolates were resistant to streptomycin, $10(8.33 \%)$ isolates to isoniazid, 4 (3.33\%) isolates to rifampicin, 4 (3.33) isolates to ethambutol. 5 (4.16\%) isolates were multidrug resistant.

Conclusion: Antituberculous drug resistance is still a threat for an effective treatment of tuberculosis and streptomycin resistance has increased. However, it is also pointed out that presence of Mycobacterium other than tuberculosis in isolates has increased.

Keywords: Drug resistance, tuberculosis, streptomycin

\section{INTRODUCTION}

Tuberculosis (TB) is an infectious disease that is caused by Mycobacterium tuberculosis complex bacilli which enter the body through the respiratory route and reside in the lungs (1). Atypical isolates such as Mycobacterium other than tuberculosis (MOTT) can also rarely cause the disease. TB is one of the most fatal diseases all around the world (1). Ehrlich-Ziehl-Neelsen (EZN) staining of sputum in order to identify acid-resistant bacteria (ARB), bacterial cultures, clinical history and chest X-ray are utilized for the diagnosis $(2,3)$. Major anti-TB drugs are streptomycin (SM), isoniazid (INH), rifampin (RIF), ethambutol (EMB) and pyrazinamide (PZA). Other anti-TB drugs are minor ones such as para-aminosalicylic acid, ethionamide, cycloserine, kanamycin, capreomycin, amikacin, thioacethazone, fluoroquinolones (ofloxacin, ciprofloxacin), rifabutin. Major drugs have stronger effects, fewer side effects than minor drugs. Nevertheless, minor drugs are preferred for multidrug-resistant TB (MDR-TB).

For the treatment, a combination of at least four types of anti-TB drugs, mostly INH, RIF, EMB, SM, and PZA, are used for the first two months (3). This is known as the bactericidal phase which has the maximum amount of bacteria and maximum risk for resistance. Then, maintenance phase follows the bactericidal phase that lasts four or seven months and in this period at least two drugs that contain isoniazid are given to the patient (3). Drug resistance should be monitored before designing the treatment plan if the drug resistance rates for SM, INH, RIF, and EMB in the region are higher than estimated percentages determined by World Health Organization (4). A long period of time is necessary for the treatment and follow-up $(1,3,4)$.

In the last twenty years, anti-tuberculosis drug resistance increased significantly all around the world 
due to inappropriate use of drugs, insufficient treatment and incomplete adherence $(5,6)$. Although the incidence of TB decreases over the years, the number of patients infected with resistant strains increases greatly (7). The drug resistance is measured by antimycobacterial susceptibility tests. There are several studies about drug resistance demonstrating the continuous change of the percentages $(8,9)$. The reason for the multitude of studies concerning drug resistance is that the treatment regimens are developed according to the drug resistance and the problem directly targets the public health.

There are 5 types of drug-resistant TB: Mono-Drug Resistant TB, Poly-Drug Resistant TB, MDR-TB, Extensively Drug Resistant TB and Extremely Drug Resistant TB (10). MDR-TB, a disease originated from Mycobacterium tuberculosis complex which is resistant to at least two drugs (especially INH and RIF), is a global threat, as it brings a great challenge in the management of TB. In 2015 there were $4.6 \%$ MDR-TB cases among an estimated 10.4 million TB cases worldwide (11). MDR-TB is a crucial problem for the TB control because it completely changes the direction of the treatment. Preventing the development of drug resistance, providing an early detection and proper treatment play an important role to prevent MDR-TB (12).

The aim of this study is to reveal the rates of the Mycobacterium tuberculosis complex bacilli resistance to major anti TB drugs (SM, INH, ETB, RIF) by evaluating the specimens that are sent to Trakya University Hospital Microbiology Laboratory in Edirne, Turkey and to compare the annual results.

\section{MATERIAL AND METHODS}

This study was approved by Scientific Research Ethics Committee of Trakya University School of Medicine. In this study, laboratory registers of the cases that were pre-diagnosed with tuberculosis between $11 / 02 / 2016$ and 31/12/2017 were scanned retrospectively. The study was carried out with data from Trakya University Hospital.

Samples of sputum, pleural fluid, urine, peritoneal fluid, tissue, cerebrospinal fluid, bronchial lavage, selective lavage, synovial fluid, endotracheal aspirate, early morning gastric washings and abscess were investigated with EZN staining. Bacterial culture examination and antimycobacterial susceptibility tests were carried out on BACTEC MGIT 960 (Becton Dickinson Diagnostic, USA) automated system. Tests were performed for the antimycobacterial drugs; SM, INH, RIF, EMB as suggested by National Committee Clinic Laboratory Standards (13). Positive cultures were also identified using the immunochromatographic assay (BD MGIT TBc Identification Test, Becton Dickinson Diagnostic, USA). If there was more than one culture positivity of the same patient, the patient's initial culture was used for drug susceptibility.

Along with the drug susceptibility test results, data including patient's age and obtaining date of the samples were retrieved using laboratory registers.

The results are recorded and grouped according to the year obtained. To compare annual results descriptive statistics as arithmetic mean \pm standard deviation, numbers and percentages were used.

\section{RESULTS}

This retrospective study included 4752 different specimens from the patients of Trakya University Hospital. Most of the specimens were sputum (2907) followed by bronchial lavage (628), urine (286) and pleural fluid (174). The mean age of the patients was $49.51 \pm 19.40$ in 2016 and $53.73 \pm 16.54$ in 2017. 111 of the specimens were identified as positive in EZN staining and 234 of the specimens were culture positive. These 234 samples belonged to 133 different patients, therefore antimycobacterial susceptibility tests were performed on their initial samples. 133 (2.79\%) of these samples showed growth of ARB. M. tuberculosis complex was found in 120 isolates, while MOTT was identified in the other 13. Antimycobacterial susceptibility tests showed that $9(7.5 \%)$ isolates were resistant to $\mathrm{SM}, 10(8.33 \%)$ isolates to $\mathrm{INH}, 4(3.33 \%)$ isolates to RIF, $4(3.33 \%)$ isolates to EMB. Results also revealed that $5(4.16 \%)$ isolates were multidrug-resistant, as one of them to INH and RIF, one to INH and EMB, two to INH and SM, while another one to all anti TB drugs that we had tested (SM, INH, RIF, EMB). Resistance to SM was 5\% in 2016 but was found to be increased to $10 \%$ in 2017 . On the contrary, INH resistance was $10 \%$ in 2016 and it decreased to $6.66 \%$ in 2017. Another annual data showed that percentage for MOTT among the isolates were $3.22 \%$ in 2016 but it was increased to $15.49 \%$ in 2017 . Yearly distribution of the results is shown in Table 1. 
Table 1: Annual values of the results.

\begin{tabular}{|c|c|c|}
\hline & $\begin{array}{c}2016 \\
\text { Number (\%) }\end{array}$ & $\begin{array}{c}2017 \\
\text { Number (\%) }\end{array}$ \\
\hline SM resistance & $3(5)$ & $6(10)$ \\
\hline INH resistance & $6(10)$ & $4(6.66)$ \\
\hline RIF resistance & $3(5)$ & $1(1.66)$ \\
\hline EMB resistance & $2(3.33)$ & $2(3.33)$ \\
\hline INH+RIF resistance & $1(1.66)$ & 0 \\
\hline INH+EMB resistance & $1(1.66)$ & 0 \\
\hline INH+SM resistance & 0 & $2(3.33)$ \\
\hline INH+RIF+EMB+SM resistance & $1(1.66)$ & 0 \\
\hline Total MDR-TB & $3(5)$ & $60(84.51)$ \\
\hline M.tuberculosis complex & $60(96.78)$ & $11(15.49)$ \\
\hline MOTT & $2(3.22)$ & 71 \\
\hline Total isolates & 62 & \\
\hline
\end{tabular}

INH: Isoniazid, RIF: Rifampin, EMB: Ethambutol, SM: Streptomycin, PIR: Pyrazinamide, MDR-TB: Multidrug-Resistant Tuberculosis, MOTT: Mycobacterium Other Than Tuberculosis

\section{DISCUSSION}

Tuberculosis is one of the most important chronic infectious diseases with its high global rates of morbidity and mortality, especially in developing countries such as Turkey (14). Therefore, preventing and therapeutic strategies against this disease are of crucial importance especially in countries where tuberculosis is endemic. Early diagnosis, proper and regular treatment of patients and patient follow-ups after treatment are essential components of tuberculosis control programs (15). Evaluation of the success of this treatment strategies can be made by analyzing the epidemiological data $(7,9)$.

Limited availability of antituberculosis drugs and the development of resistance against these drugs are not only public health concerns for developing countries, but also for the developed countries $(8,16,17)$. Among the causes of resistance development, the most important ones are noncompliance to medication and misapplication strategies. Also, inadequate drug dosing and/or absorption contribute to the resistance development $(8,14,17,18)$. The incidence of tuberculosis decreases, whereas the rate of resistance increases (7).

In our study, SM (7.5\%) and INH (8.33\%) resistances showed an increase compared to other anti-TB drugs. Previous studies in Edirne identified the resistance rates as $8.1 \%, 9.7 \%$ and $8.2 \%$ for $\mathrm{SM}, 11.5 \%, 12.6 \%$ and $14.4 \%$ for INH in 2005, 2006 and 2007, respectively. They also revealed the MDR as 6\% (13). Percentages for INH resistance (8.33\%) and MDR (4.16\%) decreased in our study. Another study on anti TB drug resistance was carried out by Tansel et al. (9) on 139 isolates between 1999 and 2001 in Edirne. Findings of the study for INH, RIF, and EMB were similar to our study. Although the percentages were consistent with our study, resistance for SM (2.2\%) was quite lower at that time. Comparison with this study indicates an increase in SM resistance.

Another study carried out in Sivas revealed that resistance to RIF (10.4\%) and EMB (9.1\%) were higher than INH (5.2\%) and SM (2.6\%) (19). MDR's value also surpassed the value in our study (4.16\%) with $14.3 \%$. In our study, resistance to RIF (3.33\%) and to ETH (3.33\%) were lower. On the other hand, resistance to SM (7.5\%) was higher.

For the surveillance in Ankara, another study was carried out by Sezen et al. (20). They detected the resistance to INH as $3,8 \%$, to RIF $0,9 \%$, to SM $3,8 \%$, EMB to $0,5 \%(20)$. All of the resistance rates were lower than those in our study. Considering these results, the location may have a role in drug resistance.

This was a retrospective study carried out using data drawn from the laboratory registers, however, patient files were not used during the study. This was a limitation of our study.

In conclusion, this study revealed that anti TB drug resistance remains a problem for the proper treatment of tuberculosis and resistance to SM has increased. Another aspect to point out is that the presence of MOTT in the isolates has increased over the years. Therefore, follow-up studies are needed to be carried out.

Ethics Committee Approval: This study was approved by Scientific Researches Committee of Trakya University School of Medicine.

Informed Consent: Written informed consent was obtained from the participants of this study.

Conflict of Interest: The authors declared no conflict of interest.

Author contributions: Concept: OÖ, CE. Design: OÖ, İEÖ, KE, CE. Supervision: OÖ, İEÖ, KE, CE. Resources: OÖ, İEÖ, KE, CE. Materials: OÖ, İEÖ, KE, CE. Data collection and/or processing: OÖ, İEÖ, KE, CE. Analysis and/or Interpretation: OÖ, İÖ, KE, CE. Literature Search: OÖ, İEÖ, KE, CE. Writing Manuscript: OÖ, İEÖ, KE, CE. Critical Review: OÖ, İEÖ, KE, CE.

Financial disclosure: The authors declared that this study received no financial support. 
Editor-in-chief's Note: Two of the authors of this article, Ozan Öner and Kubilay Elmac1 are members of the editorial board of Turkish Medical Student Journal. However, they did not take place in any stage on the editorial decision of the manuscript. The editors who evaluated this manuscript are from another institutions.

\section{REFERENCES}

1. Bañuls AL, Sanou A, Anh NT et al. Mycobacterium tuberculosis: ecology and evolution of a human bacterium. Journal of Medical Microbiology 2015;64(11):1261-9.

2. Murray PR. Mikobakteri. In: Başustaoğlu AC, Yapar M, Tanyüksel M, editors. Tibbi Mikrobiyoloji. Philadelphia: Mosby; 2014.p.277-90.

3. Akdağ R. Tüberküloz tanı ve tedavi rehberi. Ankara Türkiye Cumhuriyeti Sağlık Bakanlığı: 2011.

4. Menzies HJ, Moalosi G, Anisimova V et al. Increase in anti-tuberculosis drug resistance in Botswana: results from the fourth National Drug Resistance Survey. Int J Tuberc Lung Dis 2014;18(9):1026-33.

5. Mitchison DA. How drug resistance emerges as a result of poor compliance during short course chemotherapy for tuberculosis. Int J Tuberc Lung Dis 1998; $2: 10-5$.

6. Matteelli A, Migliori GB, Cirillo D et al. Multidrug-resistant and extensively drug-resistant Mycobacterium tuberculosis: epidemiology and control. Expert Rev Anti Infect Ther 2007;5:857-71.

7. Durmaz R. Mycobacterium tuberculosisde direnç sorunu. ANKEM Derg 2005;19(2):107-10.

8. Perinçek G, Tabakoğlu E, Otkun $\mathrm{M}$ et al. The change of antituberculosis drug resistance rate in Edirne region in 1996 and 2006. Solunum 2010;12(3):129-33.

9. Tansel Ö, Kuluoğlu F, Akata F et al. Resistance of Mycobacterium tuberculosis isolates to antituberculous agents: results of the last two years in Trakya University Hospital. Turkish Journal of Infection 2003;17(1):23-6.

10. Baylan O. Extensively drug resistant and extremely drug resistant tuberculosis forms after multi-drug resistant tuberculosis: new faces of the old disease. Mikrobiyol Bul 2011;45(1):181-95.
11. World Health Organization. Global tuberculosis report. Available from URL: http://apps.who.int/ iris/bitstream/10665/250441/1/9789241565394-eng. pdf?ua $=1 \& u a=1$ (December 2016).

12. World Health Organization. The end TB strategy. Available from URL: http://www.who.int/tb/strategy/ End_TB_Strategy.pdf?ua=1 (04/06/2018).

13. Perinçek G, Tabakoğlu E, Otkun M et al. Mycobacterium tuberculosis üremesi saptanan akciğer tüberkülozlu hastaların antitüberküloz ilaçlara direnç oranları. Tur Toraks Der 2011;12:111-3.

14. Sayğan MB, Ocak F, Cesur S et al. Susceptibilities of Mycobacterium tuberculosis strains collected from regional tuberculosis laboratories to major antituberculous drugs. Mikrobiyol Bul 2007;41:403-9.

15. Baylan O, Kısa BÖ, Albay A et al. Mikobakteriyoloji laboratuarımızda 2002 yılında tüberküloz olgularından izole edilen Mycobacterium tuberculosis kompleks (MTC) suşları ve antitüberküloz ilaç duyarlılık sonuçları. Gülhane Tıp Dergisi 2003;45(3):256-62.

16. Khalid FA, Hamid ZA, Mukhtar MM. Tuberculosis drug resistance isolates from pulmonary tuberculosis patients, Kassala State, Sudan. Int J Mycobacteriol 2015;4(1):44-7.

17. Tavanaee Sani A, Shakiba A, Salehi M et al. Epidemiological characterization of drug resistance among Mycobacterium tuberculosis isolated from patients in northeast of Iran during 2012-2013. Biomed Res Int 2015;2015:747085.

18. Baylan O, Albay A, Kısa Ö et al. Detection of primary drug resistance rates of Mycobacterium tuberculosis complex strains isolated between 2002-2003 years and comparison with the data of 1998-2001 period. Mikrobiyol Bul 2005;39:153-60.

19. Bozdağ İ, Coşar AD, Özer A. Klinik örneklerden izole edilen Mycobacterium tuberculosis kompleks suşlarının antibiyotiklere direnç oranları. Tıp Araştırmalar1 Dergisi 2015;13(1):6-10.

20. Sezen F, Albayrak N, Özkara Ş et al. The first step for national tuberculosis laboratory surveillance; Ankara, 2011. Mikrobiyol Bul 2015;49(2):143-55. 